\title{
Anti-inflammatory Properties of Cannabidiol, a Nonpsychotropic Cannabinoid, in Experimental Allergic Contact Dermatitis
}

\author{
Stefania Petrosino, Roberta Verde, Massimo Vaia, Marco Allarà, Teresa luvone, \\ and Vincenzo Di Marzo \\ Endocannabinoid Research Group, Istituto di Chimica Biomolecolare, Consiglio Nazionale delle Ricerche, Pozzuoli, Napoli, Italy \\ (S.P., R.V., M.A., V.D.); Epitech Group SpA, Saccolongo, Padova, Italy (S.P., M.A.); and Dipartimento di Farmacologia \\ Sperimentale, Università di Napoli “Federico II", Napoli, Italy (M.V., T.I.)
}

Received July 29, 2017; accepted March 6, 2018

\begin{abstract}
Phytocannabinoids modulate inflammatory responses by regulating the production of cytokines in several experimental models of inflammation. Cannabinoid type- $2\left(\mathrm{CB}_{2}\right)$ receptor activation was shown to reduce the production of the monocyte chemotactic protein-2 (MCP-2) chemokine in polyinosinicpolycytidylic acid [poly-(l:C)]-stimulated human keratinocyte $(\mathrm{HaCaT})$ cells, an in vitro model of allergic contact dermatitis (ACD). We investigated if nonpsychotropic cannabinoids, such as cannabidiol (CBD), produced similar effects in this experimental model of ACD. HaCaT cells were stimulated with poly$(\mathrm{l}: \mathrm{C})$, and the release of chemokines and cytokines was measured in the presence of CBD or other phytocannabinoids (such as cannabidiol acid, cannabidivarin, cannabidivarinic acid, cannabichromene, cannabigerol, cannabigerolic acid, cannabigevarin, tetrahydrocannabivarin, and tetrahydrocannabivarinic
\end{abstract}

acid) and antagonists of $\mathrm{CB}_{1}, \mathrm{CB}_{2}$, or transient receptor potential vanilloid type-1 (TRPV1) receptors. HaCaT cell viability following phytocannabinoid treatment was also measured. The cellular levels of endocannabinoids [anandamide (AEA), 2-arachidonoylglycerol] and related molecules (palmitoylethanolamide, oleoylethanolamide) were quantified in poly-(I:C)-stimulated HaCaT cells treated with CBD. We show that in poly-(I:C)-stimulated HaCaT cells, CBD elevates the levels of $A E A$ and dose-dependently inhibits poly-(I:C)induced release of MCP-2, interleukin-6 (IL-6), IL-8, and tumor necrosis factor- $\alpha$ in a manner reversed by $\mathrm{CB}_{2}$ and TRPV1 antagonists 6-iodopravadoline (AM630) and 5'-iodio-resiniferatoxin (I-RTX), respectively, with no cytotoxic effect. This is the first demonstration of the anti-inflammatory properties of CBD in an experimental model of ACD.

\section{Introduction}

Allergic contact dermatitis (ACD), a form of delayed-type hypersensitivity, is a typical T-cell-mediated skin inflammatory response that occurs after cutaneous exposure to an allergen. In particular, following first application to the skin, epidermal Langerhans cells (LCs) take up the allergen, process it, and migrate toward the regional lymph nodes, where the antigen is presented to naïve $\mathrm{T}$ cells, which, once activated, migrate toward peripheral tissues. During this process, known as "the sensitization phase," LCs convert from a

S.P. and M.A. are employees of Epitech Group SpA. V.D. is the recipient of research grants, provides consultancy services, and performs sponsored research for GW Research Ltd. No other authors have conflicts of interests.

This work was partly supported by a research grant from GW Research Ltd to V.D.

https://doi.org/10.1124/jpet.117.244368. "quiescent" into an "activated" functional state. This activation of LCs is initiated by keratinocytes, which secrete inflammatory cytokines such as interleukin (IL)-6, IL-2, tumor necrosis factor- $\alpha$ (TNF- $\alpha$ ), and granulocyte-macrophage colony-stimulating factor (GM-CSF), which in turn contribute to LC activation and migration (Enk and Katz, 1992; Becker and Knop, 1993). The subsequent allergen application induces "the elicitation phase" of ACD that involves the degranulation of mast cells, vasodilatation and influx of neutrophils, followed by substantial leukocyte infiltration into tissue and edema formation peaking between 24 and 48 hours. This late-phase response has the same direct effects on the skin as the first allergen contact during sensitization (i.e., proinflammatory effects, $\mathrm{LC}$ activation), but $\mathrm{T}$ cell activation is subjected to the release of cytokines produced by $\mathrm{T}$ lymphocytes, which amplify the inflammatory response by generating a process that leads to further accumulation of infiltrating cells and resulting

ABBREVIATIONS: ACD, allergic contact dermatitis; AEA, anandamide ( $N$-arachidonoyl-ethanolamine); 2-AG, 2-arachidonoylglycerol; AM251, 1(2,4-dichlorophenyl)-5-(4-iodophenyl)-4-methyl-N-(1-piperidyl)pyrazole-3-carboxamide; AM630, 6-iodopravadoline; APCI, atmospheric pressure chemical ionization; $\mathrm{CB}_{1}$ and $\mathrm{CB}_{2}$, cannabinoid receptors of type-1 and -2; $\mathrm{CBC}$, cannabichromene; $\mathrm{CBD}$, cannabidiol; CBDA, cannabidiol acid; CBDV, cannabidivarin; CBDVA, cannabidivarinic acid; CBG, cannabigerol; CBGA, cannabigerolic acid; CBGV, cannabigevarin; DMSO, dimethylsulfoxide; DNFB, 2,4-dinitrofluorobenzene; G-CSF, granulocyte colony-stimulating factor; GM-CSF, granulocyte-macrophage colonystimulating factor; HaCaT, human keratinocytes; IL, interleukin; I-RTX, 5'-iodio-resiniferatoxin; LC, Langerhans cell; MCP, monocyte chemotactic protein; MTT, 3-(4,5-dimethylthiazol-2yl)-2,5-diphenyl tetrazolium bromide; OEA, oleoylethanolamide; PEA, palmitoylethanolamide; poly-(l:C), polyinosinic-polycytidylic acid; THC, $\Delta^{9}$-tetrahydrocannabinol; THCV, tetrahydrocannabivarin; THCVA, tetrahydrocannabivarinic acid; TNF- $\alpha$, tumor necrosis factor- $\alpha$; TRPV1, transient receptor potential vanilloid type-1 channel; URB597, [3-(3-Carbamoylphenyl)phenyl] N-cyclohexylcarbamate. 
in clinically manifested ACD (van Loveren et al., 1983; Watanabe et al., 2002). However, the production of cytokines (such as IL-1, IL-6, and IL-8) from keratinocytes, as well as the induction of adhesion molecules (such as intercellular adhesion molecule) in keratinocytes, is also required for $\mathrm{T}$ cell activation, chemotactic activity, and adhesion in the epidermis, indicating that these cells have a crucial role in ACD (Barker, 1992).

Although many studies reported anti-inflammatory properties for two major cannabinoids present in marijuana, such as the psychoactive compound $\Delta^{9}$-tetrahydrocannabinol (THC) and the nonpsychotropic compound cannabidiol (CBD) (Burstein and Zurier, 2009; Burstein, 2015), the first evidence of the anti-inflammatory effects of cannabinoids in an animal model of ACD was reported by Oka et al. (2006), and soon thereafter by Karsak et al. (2007) in collaboration with our group (Karsak et al., 2007). In particular, it was demonstrated that both subcutaneous and topical application of THC attenuated ACD in 2,4-dinitrofluorobenzene (DNFB)-treated wild-type mice (Karsak et al., 2007). THC significantly decreased ear swelling and reduced the recruitment of Gr-positive granulocytes in comparison with untreated mice (Karsak et al., 2007). Intriguingly, the cannabinoid type-2 $\left(\mathrm{CB}_{2}\right)$ receptor antagonist SR144528 was reported, on the one hand, to counteract DNFB-induced (Ueda et al., 2005) and oxazoline-induced (Oka et al., 2006) ACD in mice, and on the other hand, to inhibit the anti-inflammatory effect of THC on this condition (Karsak et al., 2007). Nevertheless, Karsak et al. (2007) also demonstrated that the synthetic cannabinoid agonist HU-210 was able to reduce the production of the monocyte chemotactic protein-2 (MCP-2) chemokine in polyinosinicpolycytidylic acid [poly-(I:C)]-stimulated human keratinocytes (HaCaT) cells, an in vitro model of the first phase of ACD. More recently, THC was suggested to inhibit DNFB-induced dermatitis also via non- $\mathrm{CB}_{1}$, non- $\mathrm{CB}_{2}-$ mediated pathways (Gaffal et al., 2013). Indeed, we reported that the anti-inflammatory compound palmitoylethanolamide (PEA), which belongs to the same chemical class as the endocannabinoid anandamide (AEA) but is unable to directly activate cannabinoid receptors (Petrosino and Di Marzo, 2017), also reduced the production of MCP-2 in poly-(I:C)-stimulated HaCaT cells, as well as the DNFB-induced ear skin edema in mice (Petrosino et al., 2010). Moreover, we also demonstrated that, although PEA is known to directly activate the peroxisome proliferator-activated receptor- $\alpha$ (Lo Verme et al., 2005), only the selective antagonism of transient receptor potential vanilloid type-1 (TRPV1) channels reversed the effects of PEA on MCP-2 production in poly(I:C)-stimulated $\mathrm{HaCaT}$ cells and on the first, keratinocytemediated stage of DNFB-induced ear skin edema in mice (Petrosino et al., 2010), whereas $\mathrm{CB}_{2}$ receptors were involved in PEA effects in the late, mast cell-mediated stage of this in vivo model of ACD (Vaia et al., 2016). These previous data are in agreement with the indirect stimulatory actions of PEA on TRPV1 and $\mathrm{CB}_{2}$ and with the role of TRPV1 and $\mathrm{CB}_{2}$ in ACD (De Petrocellis et al., 2001; Petrosino et al., 2016).

On the basis of this background, and in view of the fact that it has been demonstrated that CBD also stimulates and desensitizes TRPV1 channels (De Petrocellis et al., 2011; Iannotti et al., 2014), the aim of the present study was to investigate the pharmacological effects of this and other
A
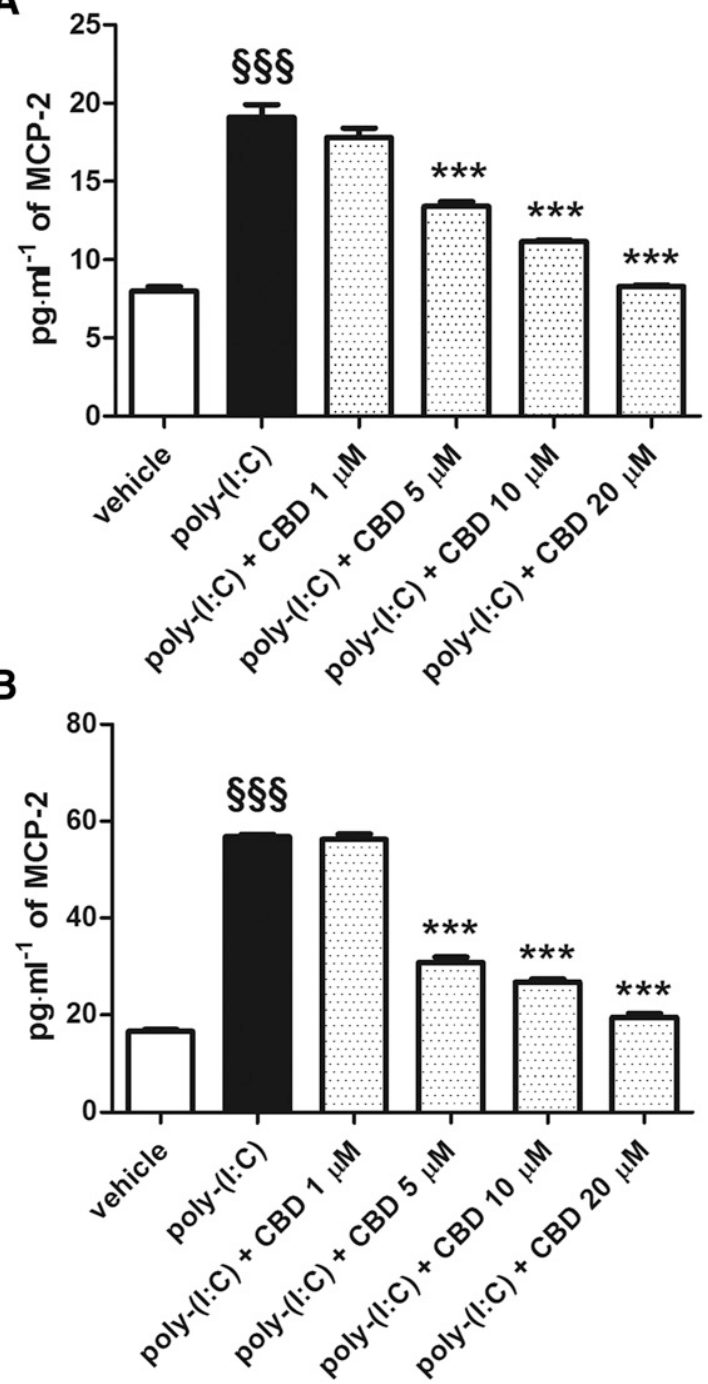

C

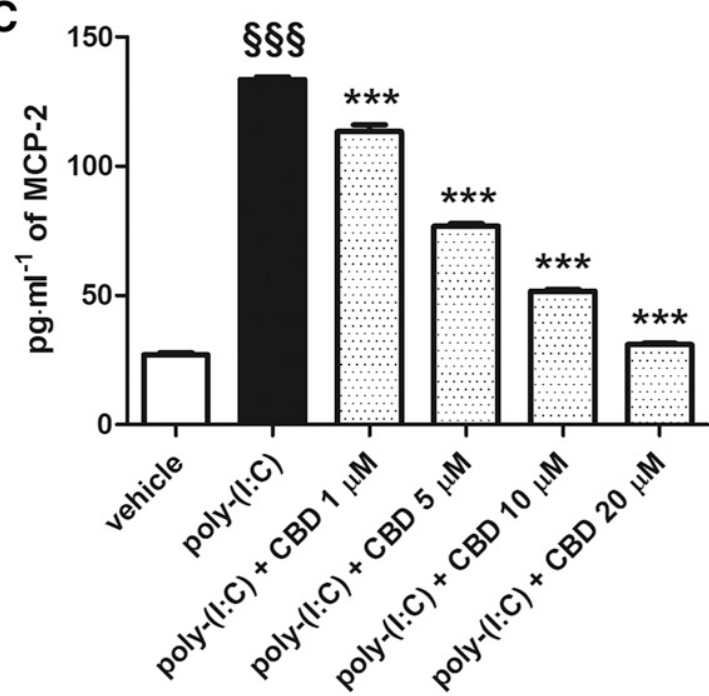

Fig. 1. CBD reduces MCP-2 levels in poly-(I:C)-stimulated HaCaT cells. Enzyme-linked immunosorbent assay for MCP-2 release in the supernatants of poly-(I:C)-stimulated $\mathrm{HaCaT}$ cells $(100 \mu \mathrm{g} / \mathrm{ml})$ in the presence of vehicle or CBD $(1,5,10$, and $20 \mu \mathrm{M})$ for $6(\mathrm{~A}), 12(\mathrm{~B})$, and 24 hours (C) at $37^{\circ} \mathrm{C}$ in $5 \% \mathrm{CO}_{2}$. Data represent the mean \pm S.E.M. of three independent experiments performed in triplicate. ${ }^{\S \S \S} P<0.001$ vs. vehicle; ${ }^{* * *} P<0.001$ vs. poly-(I:C). Assay range for MCP-2, 0.8-200 pg/ml. 
nonpsychotropic phytocannabinoids in an in vitro model of ACD, as well as to identify the molecular target(s) for its actions in the in vitro model.

\section{Materials and Methods}

Drugs and Reagents. Cell culture media, antibiotics, and 3-(4,5dimethylthiazol-2yl)-2,5-diphenyl tetrazolium bromide (MTT) were purchased from Sigma-Aldrich (Milano, Italy). Poly-(I:C) was purchased from InvivoGen (Aurogene Srl, Roma, Italy). Botanical CBD, cannabidiol acid (CBDA), cannabidivarin (CBDV), cannabidivarinic acid (CBDVA), cannabichromene (CBC), cannabigerol (CBG), cannabigerolic acid (CBGA), cannabigevarin (CBGV), tetrahydrocannabivarin (THCV), and tetrahydrocannabivarinic acid (THCVA)
( $>99.9 \%$ purity) were provided by GW Research Ltd. (Cambridge, UK). 1-(2,4-dichlorophenyl)-5-(4-iodophenyl)-4-methyl-N-(1-piperidyl) pyrazole-3-carboxamide (AM251), 6-iodopravadoline (AM630) 5'iodio-resiniferatoxin (I-RTX), AEA, and [3-(3-Carbamoylphenyl)phenyl] N-cyclohexylcarbamate (URB597) were purchased from Tocris Bioscience (Space Import-Export Srl, Milano, Italy). The human MCP-2 enzyme-linked immunosorbent assay kit was purchased from RayBiotech, Inc. (Tebu-Bio Srl, Milano, Italy). The Bio-Plex Pro human cytokine assay was purchased from Bio-Rad (Life Science, Segrate, Milano, Italy). Deuterated standards- $\left[{ }^{2} \mathrm{H}\right]_{8}$-AEA, $\left[{ }^{2} \mathrm{H}\right]_{5}$-2-arachidonoylglycerol (2-AG), $\left[{ }^{2} \mathrm{H}\right]_{4}$-PEA, and $\left[{ }^{2} \mathrm{H}\right]_{2}$-oleoylethanolamide (OEA) - were purchased from Cayman Chemical (Cabru SAS, Arcore, Italy).

Cell Culture. The HaCaT cell line (item number: 300493; mycoplasma-specific polymerase chain reaction: negative) was purchased from CLS Cell Lines Service (Eppelheim, Germany) and
A
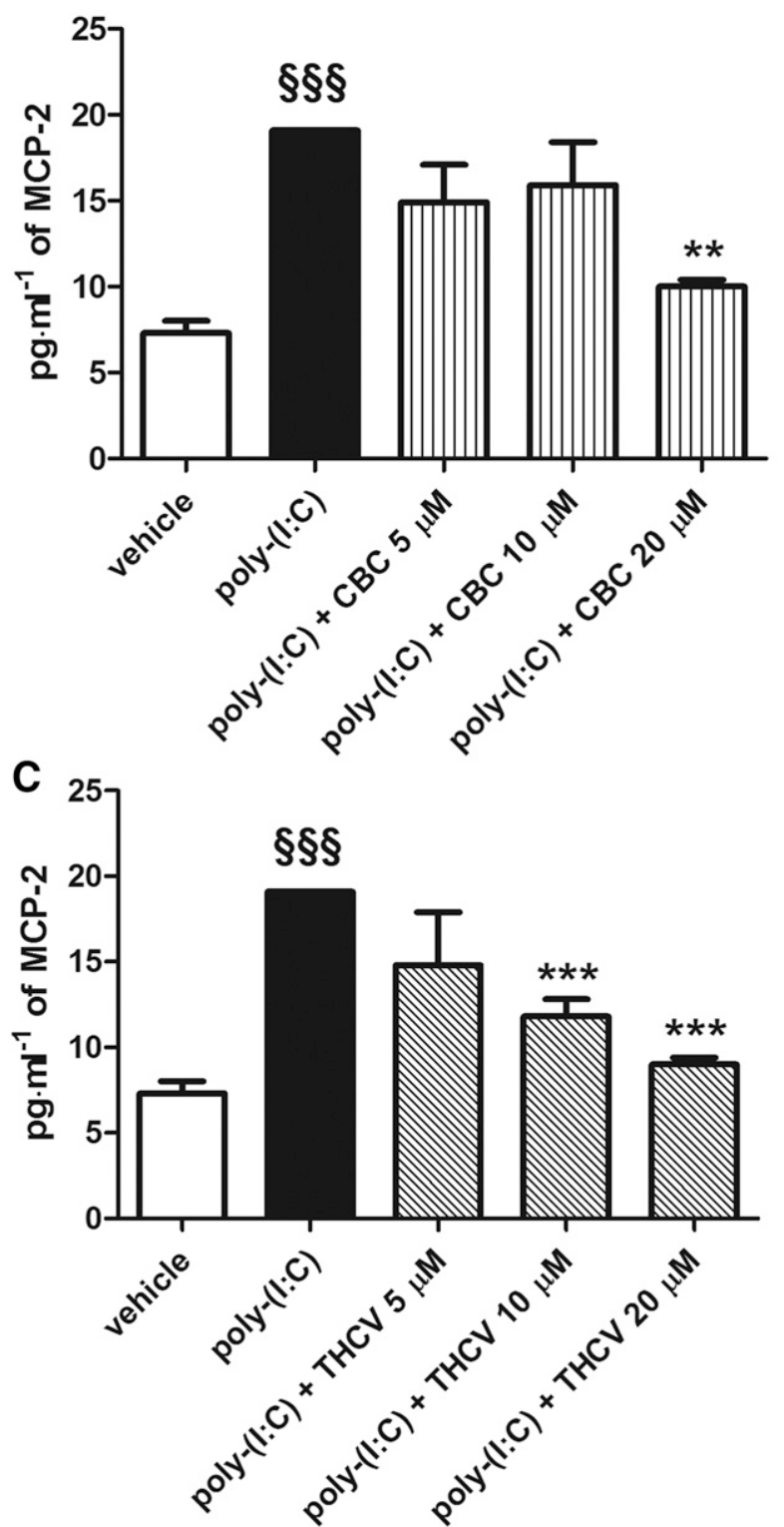

B
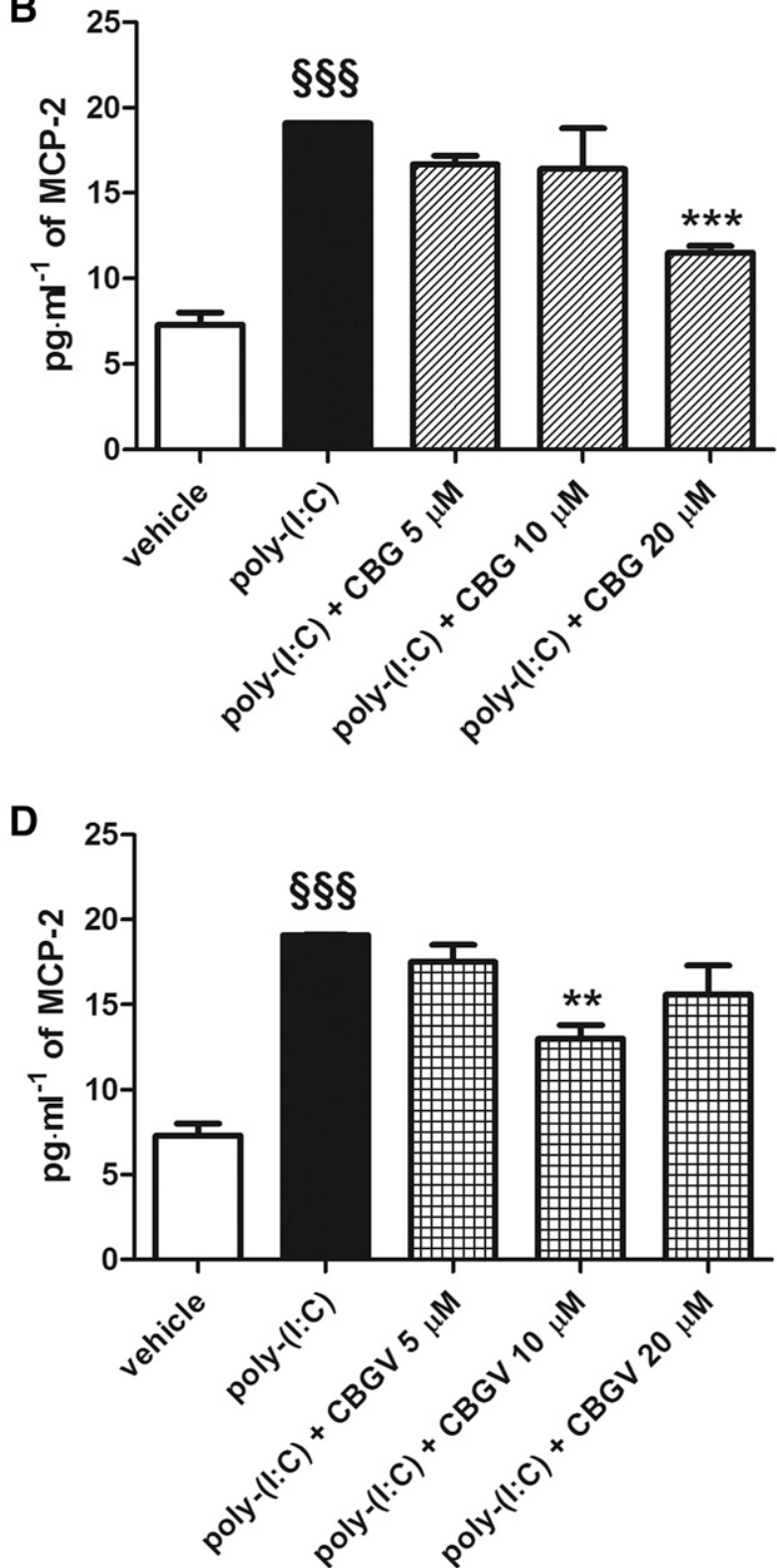

Fig. 2. CBC, CBG, THCV, and CBGV reduce MCP-2 levels in poly-(I:C)-stimulated HaCaT cells. Enzyme-linked immunosorbent assay for MCP-2 release in the supernatants of poly-(I:C)-stimulated HaCaT cells $\left(100 \mu \mathrm{g} / \mathrm{ml}, 6 \mathrm{hours}, 37^{\circ} \mathrm{C}\right)$ in the presence of vehicle or CBC (A), CBG (B), THCV (C), and CBGV (D) (all tested at 5, 10, and $20 \mu \mathrm{M})$. Data represent the mean \pm S.E.M. of three independent experiments performed in triplicate. ${ }^{\$ \$ \$ \$} P<0.001$ vs. vehicle; $* * P<0.01 ; * * * P<0.001$ vs. poly-(I:C). Assay range for MCP-2, $0.8-200 \mathrm{pg} / \mathrm{ml}$. 
cultured in Dulbecco's modified Eagle's medium supplemented with glutamine $(2 \mathrm{mM})$, penicillin $(400 \mathrm{U} / \mathrm{ml})$, streptomycin $(50 \mathrm{mg} / \mathrm{ml})$, and $10 \%$ fetal bovine serum at $37^{\circ} \mathrm{C}$ in humidified $5 \% \mathrm{CO}_{2}$.

Poly-(I:C)-Induced ACD in HaCaT Cells. HaCaT cells were plated into 24-well culture plates at a cell density of $2 \times 10^{5}$ cells per well, and after 1 day were stimulated with $100 \mu \mathrm{g} / \mathrm{ml}$ poly-(I:C) (Petrosino et al., 2010) or vehicle (water) and incubated for 6, 12, and 24 hours at $37^{\circ} \mathrm{C}$ in $5 \% \mathrm{CO}_{2}$. To study the effect of CBD, poly-(I:C)stimulated $\mathrm{HaCaT}$ cells were treated with $\mathrm{CBD}(1,5,10$, and $20 \mu \mathrm{M})$ or vehicle (methanol) for the indicated times. To study the effect of $\mathrm{CB}_{1}$, $\mathrm{CB}_{2}$, and TRPV1 antagonists, poly-(I:C)-stimulated HaCaT cells were treated with $\operatorname{AM} 251(1,2.5$, and $5 \mu \mathrm{M}), \operatorname{AM} 630(0.01,0.1$, and $1 \mu \mathrm{M})$, and I-RTX $(0.01,0.1$, and $1 \mu \mathrm{M})$, respectively, in the presence or absence of $\mathrm{CBD}(20 \mu \mathrm{M})$ for the indicated times. AM251 was dissolved in methanol, AM630 and I-RTX in dimethylsulfoxide (DMSO). The effects of the other phytocannabinoids (all dissolved in DMSO), such as CBDA, CBDV, CBDVA, CBC, CBG, CBGA, CBGV, THCV, and THCVA (all tested at 5,10 , and $20 \mu \mathrm{M}$ ), on MCP-2 production in poly-(I:C)-stimulated $\mathrm{HaCaT}$ cells were also investigated. Finally, the effects of the endocannabinoid AEA (dissolved in methanol) and of URB597 (dissolved in methanol) (a selective inhibitor of the major enzyme responsible for AEA inactivation, fatty acid amide hydrolase) on MCP-2 production in poly-(I:C)-stimulated HaCaT cells were also studied. After 6, 12, and 24 hours, the supernatants were used for MCP-2 enzyme-linked immunosorbent assay and for Bio-Plex Pro assay [IL-1 $\beta$, IL-2, IL-6, IL-8, granulocyte colony-stimulating factor (G-CSF), GM-CSF, TNF- $\alpha$ ], according to the manufacturer's instructions. Results are expressed as picograms per milliliter of released MCP-2 and cytokines.

Cell Viability. Cell viability was measured after 6, 12, and 24 hours in HaCaT cells treated with CBD, CBC, CBG, THCV, CBGV (all tested at 10 and $20 \mu \mathrm{M}$ ), or vehicle by using the MTT colorimetric assay. In brief, after 6,12 , and 24 hours, $\mathrm{HaCaT}$ cells were incubated with MTT $(5 \mathrm{mg} / \mathrm{ml})$ for 3 hours at $37^{\circ} \mathrm{C}$ in $5 \% \mathrm{CO}_{2}$. After 3 hours, $\mathrm{HaCaT}$ cells were lysed with DMSO, and absorbance was measured at $630 \mathrm{~nm}$. Results are expressed as percentage of cell viability, where optical density values from vehicle-treated cells were defined as $100 \%$ of cell viability.

Analysis of Endocannabinoids and Related $N$ Acylethanolamines. HaCaT cells were plated into six-well culture plates at a cell density of $9 \times 10^{5}$ cells per well, and after 1 day were stimulated with poly-(I:C) $(100 \mu \mathrm{g} / \mathrm{ml})$ and treated with CBD $(20 \mu \mathrm{M})$ or vehicle, and incubated for 6,12 , and 24 hours at $37^{\circ} \mathrm{C}$ in $5 \% \mathrm{CO}_{2}$. After the indicated times, the resulting cells and supernatants were subjected to measurement of endocannabinoids such as AEA and 2-AG, and $N$-acylethanolamines related to AEA, i.e., PEA and OEA.

Cells and supernatants were homogenized in a solution of chloroform/methanol/Tris-HCl $50 \mathrm{mM}, \mathrm{pH} 7.4$ (2:1:1 by vol.), containing $10 \mathrm{pmol}$ of $\left[{ }^{2} \mathrm{H}\right]_{8}$-AEA and 5 pmol of $\left[{ }^{2} \mathrm{H}\right]_{5}-2-\mathrm{AG},\left[{ }^{2} \mathrm{H}\right]_{4}$-PEA, and $\left[{ }^{2} \mathrm{H}\right]_{2^{-}}$ OEA as internal deuterated standards. The lipid-containing organic phase was prepurified by open-bed chromatography on silica gel (Bisogno et al., 1997; Di Marzo et al., 2001), and fractions obtained by eluting the column with a solution of chloroform/methanol (90:10 by vol.) were analyzed by liquid chromatography-atmospheric pressure chemical ionization (APCI)-mass spectrometry by using a Shimadzu high-performance liquid chromatography apparatus (LC10ADVP) coupled to a Shimadzu (LCMS-2020) quadrupole mass spectrometer via a Shimadzu APCI interface. Liquid chromatography-APCI-mass spectrometry analyses of AEA, 2-AG, PEA, and OEA were carried out in the selected ion monitoring mode (Marsicano et al., 2002), using $\mathrm{m} / \mathrm{z}$ values of molecular ions +1 for deuterated and undeuterated compounds, respectively, as follows: 356 and 348 (AEA), 384.35 and 379.35 (2-AG), 304 and 300 (PEA), and 328 and 326 (OEA). AEA, 2-AG, PEA, and OEA levels were calculated on the basis of their area ratio with the internal deuterated standard signal areas, and their amounts (picomole) were normalized per milliliter of volume.

Statistics. Statistical analyses were performed using GraphPad Prism version 5.0 (GraphPad Software Inc., San Diego, CA). The data
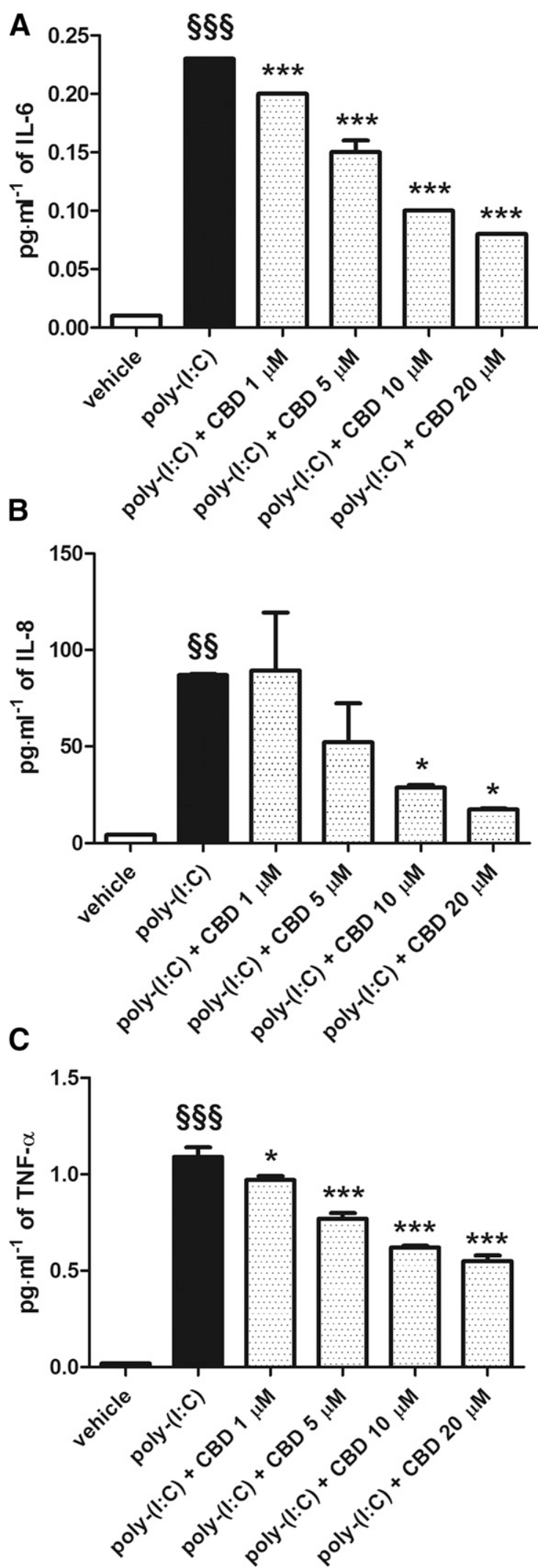

Fig. 3. CBD reduces $\mathrm{IL}-6$, IL-8, and TNF- $\alpha$ levels in poly-(I:C)-stimulated HaCaT cells after 6 hours. Bio-Plex Pro assay for $\mathrm{IL}-6(\mathrm{~A}), \mathrm{IL}-8(\mathrm{~B})$, and TNF- $\alpha(\mathrm{C})$ release in the supernatants of poly-(I:C)-stimulated HaCaT cells $(100 \mu \mathrm{g} / \mathrm{ml}$, 6 hours, $\left.37^{\circ} \mathrm{C}\right)$ in the presence of vehicle or CBD $(1,5,10$, and $20 \mu \mathrm{M})$. Data represent the mean \pm S.E.M. of three independent experiments performed in triplicate. ${ }^{5 \$ 8} P<0.001$ vs. vehicle; $* P<0.05$; $* * * P<0.001$ vs. poly-(I:C). Assay range for IL-6, $37.68 \mathrm{pg} / \mathrm{ml}$; for IL-8, $42.15 \mathrm{pg} / \mathrm{ml}$; and for TNF- $\alpha, 64.80 \mathrm{pg} / \mathrm{ml}$ 

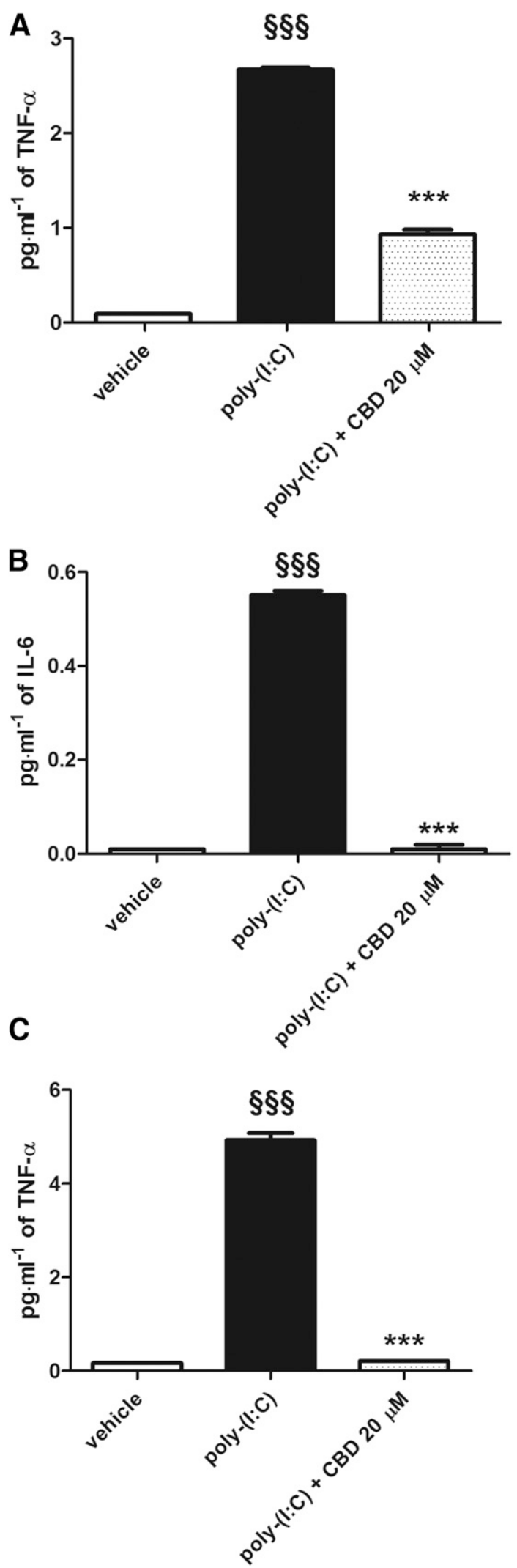

Fig. 4. CBD reduces IL-6 and TNF- $\alpha$ levels in poly-(I:C)-stimulated HaCaT cells after 12 and 24 hours. (A) Bio-Plex Pro assay for TNF- $\alpha$ release in the supernatants of poly-(I:C)-stimulated HaCaT cells $\left(100 \mu \mathrm{g} / \mathrm{ml}, 12\right.$ hours, $\left.37^{\circ} \mathrm{C}\right)$ in the presence of vehicle or CBD $(20 \mu \mathrm{M})$. Bio-Plex Pro assay for IL-6 (B) and TNF- $\alpha(\mathrm{C})$ release in the supernatants of poly-(I:C)-stimulated HaCaT cells $\left(100 \mu \mathrm{g} / \mathrm{ml}, 24\right.$ hours, $\left.37^{\circ} \mathrm{C}\right)$ in the presence of vehicle or CBD $(20 \mu \mathrm{M})$. Data represent the mean \pm S.E.M. of are expressed as means \pm S.E.M. Student's $t$ test or one-way analysis of variance followed by Newman-Keuls multiple comparison test were used for analysis. $P$ values $<0.05$ were considered statistically significant.

\section{Results}

CBD Reduces MCP-2 Protein Levels in Poly-(I:C)Stimulated HaCaT Cells. We investigated the effects of CBD, CBDA, CBDV, CBDVA, CBC, CBG, CBGA, CBGV, THCV, and THCVA on MCP-2 protein levels in poly-(I:C)stimulated $\mathrm{HaCaT}$ cells. HaCaT cells stimulated for 6,12 , and 24 hours with poly-(I:C) $(100 \mu \mathrm{g} / \mathrm{ml})$ and treated with the vehicle of the phytocannabinoids produced significantly higher levels of the MCP-2 chemokine as compared with vehicle-stimulated $\mathrm{HaCaT}$ cells (Fig. 1). When $\mathrm{HaCaT}$ cells were costimulated with poly-(I:C) and $\operatorname{CBD}(1,5,10$, and $20 \mu \mathrm{M})$ for 6 hours, we observed a strong concentrationdependent reduction of MCP-2 protein levels as compared with poly-(I:C)-stimulated HaCaT cells treated with the vehicle of CBD (Fig. 1A). The maximum effect was observed at the highest concentration of CBD tested $(20 \mu \mathrm{M})$, as compared with poly-(I:C)-stimulated $\mathrm{HaCaT}$ cells treated with the vehicle of CBD (Fig. 1A). Likewise, $\operatorname{CBD}(1,5,10$, and $20 \mu \mathrm{M}$ ), in a concentration-dependent manner, was also able to strongly reduce MCP-2 production in poly-(I:C)stimulated HaCaT cells after 12 and 24 hours, and the maximum effect was also observed with $20 \mu \mathrm{M}$ CBD (Fig. 1, $\mathrm{B}$ and $\mathrm{C})$. On the contrary, when $\mathrm{HaCaT}$ cells were costimulated with poly-(I:C) and CBC or CBG, no effect was observed at low concentrations ( 5 and $10 \mu \mathrm{M}$ ), although at the highest concentration tested $(20 \mu \mathrm{M})$, these two phytocannabinoids were able to reduce MCP-2 production (Fig. 2, A and B). Likewise, when $\mathrm{HaCaT}$ cells were costimulated with poly-(I: C), THCV had no effect at the lowest concentration tested (5 $\mu \mathrm{M}$ ), but at 10 and $20 \mu \mathrm{M}$, it was able to reduce MCP-2 production (Fig. 2C). CBGV was able to reduce MCP-2 production only at $10 \mu \mathrm{M}$ (Fig. 2D). No effect was observed on MCP-2 protein levels after treatment of poly-(I:C)-stimulated $\mathrm{HaCaT}$ cells with CBDA, CBDV, CBDVA, CBGA, and THCVA as compared with poly-(I:C)-stimulated $\mathrm{HaCaT}$ cells treated with the respective vehicles (data not shown). Likewise, no significant variation was observed on MCP-2 protein levels after $\mathrm{HaCaT}$ cells were treated with $\mathrm{CBD}$ or the other phytocannabinoids alone (at highest concentration tested, $20 \mu \mathrm{M}$ ), i.e., in the absence of poly-(I:C), as compared with vehicle-treated $\mathrm{HaCaT}$ cells (data not shown), indicating that this concentration of CBD was not cytotoxic.

CBD Reduces IL-6, IL-8, and TNF- $\alpha$ Protein Levels in Poly-(I:C)-Stimulated HaCaT Cells. We also investigated the effects of CBD, CBC, CBG, THCV, and CBGV on the production of different cytokines (IL-1 $\beta$, IL-2, IL-6, IL-8, G-CSF, GM-CSF, TNF- $\alpha$ ) in poly-(I:C)-stimulated HaCaT cells. HaCaT cells stimulated for 6 hours with poly-(I:C) $(100 \mu \mathrm{g} / \mathrm{ml})$ and treated with the vehicle of the phytocannabinoids produced significantly higher levels of only IL- 6 , IL- 8 , and TNF- $\alpha$, as compared with vehicle-stimulated $\mathrm{HaCaT}$ cells (Fig. 3). CBD

three independent experiments performed in triplicate. ${ }^{\S \S \S} P<0.001$ vs. vehicle; $* * * P<0.001$ vs. poly-(I:C). Assay range for IL-6, $37.68 \mathrm{pg} / \mathrm{ml}$; and for TNF- $\alpha, 64.80 \mathrm{pg} / \mathrm{ml}$. 
$(1,5,10$, and $20 \mu \mathrm{M})$, in a concentration-dependent manner, was able to strongly reduce IL- 6 and TNF- $\alpha$ protein levels in poly-(I: C)-stimulated HaCaT cells, as compared with poly-(I:C)stimulated HaCaT cells treated with the vehicle of CBD (Fig. 3,
A and C). IL-8 protein levels were strongly reduced only by the two highest concentrations of CBD tested (10 and $20 \mu \mathrm{M})$ (Fig. 3B). When HaCaT cells were stimulated for 12 hours with poly-(I: C) and treated with the vehicle of the phytocannabinoids, we only
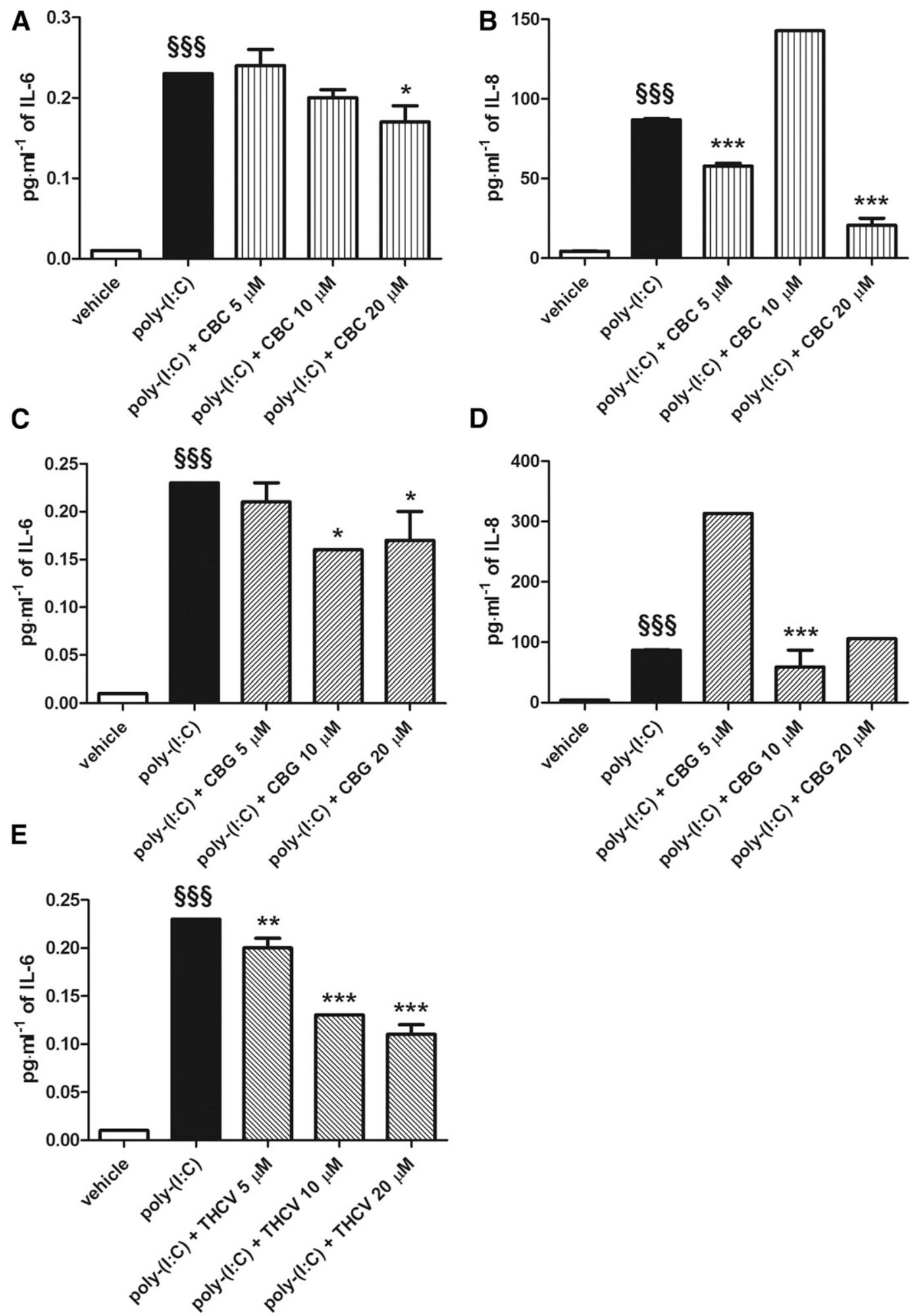

Fig. 5. CBC, CBG, and THCV reduce IL-6 and IL-8 levels in poly-(I:C)-stimulated HaCaT cells after 6 hours. Bio-Plex Pro assay for IL-6 (A, C, and E) and IL-8 (B and D) release in the supernatants of poly-(I:C)-stimulated HaCaT cells (100 $\mu \mathrm{g} / \mathrm{ml}, 6$ hours, $\left.37^{\circ} \mathrm{C}\right)$ in the presence of vehicle or CBC, CBG, and THCV (all tested at 5, 10, and $20 \mu \mathrm{M}$ ). Data represent the mean \pm S.E.M. of three independent experiments performed in triplicate. ${ }^{\S \S \S} P<0.001$ vs. vehicle; ${ }^{*} P<0.05 ; * * P<0.01$; *** $P<0.001$ vs. poly-(I:C). Assay range for IL-6, $37.68 \mathrm{pg} / \mathrm{ml}$; and for IL-8, $42.15 \mathrm{pg} / \mathrm{ml}$. 
observed a strong increase of TNF- $\alpha$ protein levels (Fig. 4A), which was significantly reduced by the highest concentration of CBD tested $(20 \mu \mathrm{M})$ (Fig. 4A). When HaCaT cells were stimulated for 24 hours with poly-(I:C) and treated with the vehicle of the phytocannabinoids, we observed a strong increase in both IL-6 (Fig. 4B) and TNF- $\alpha$ (Fig. 4C) protein levels, which were again strongly reduced by treatment with CBD $20 \mu \mathrm{M}$ (Fig. $4, \mathrm{~B}$ and C). On the contrary, the other phytocannabinoids found here to produce anti-inflammatory effects on MCP-2 levels were able to downregulate only some of these cytokines after 6 hours, i.e., 1) CBC $(20 \mu \mathrm{M})$ was able to reduce only IL-6 and IL-8 levels (Fig. 5, A and B), 2) CBG (10 $\mu \mathrm{M})$ was able to reduce only IL-6 and IL-8 levels (Fig. 5, B and C), and 3) THCV (20 $\mu \mathrm{M})$ was able to reduce only IL-6 levels (Fig. 5D). No effect was observed on the levels of other cytokines, i.e., IL- $1 \beta$, IL-2, G-CSF, and GM-CSF, after stimulation of $\mathrm{HaCaT}$ cells with poly-(I:C) in the presence or absence of the other phytocannabinoids (data not shown).

CBD and Other Phytocannabinoids Are Not Cytotoxic to HaCaT Cells. No cytotoxicity was observed after treatment of $\mathrm{HaCaT}$ cells for 6 hours with CBD, CBC, CBG, THCV, or CBGV at the highest concentrations tested (10 and $20 \mu \mathrm{M}$ ) (Fig. 6A). Likewise, no cytotoxicity was observed after treatment of HaCaT cells for 12 and 24 hours with 10 and $20 \mu \mathrm{M}$ CBD (Fig. 6B). These results indicate that the decreased MCP-2 and/or cytokine levels in poly-(I:C)-stimulated $\mathrm{HaCaT}$ cells were due to the anti-inflammatory effects of these compounds.

$\mathrm{CB}_{1}$ Receptors Do Not Mediate the Action of CBD in Poly-(I:C)-Stimulated HaCaT Cells. We investigated the effect of a $\mathrm{CB}_{1}$ receptor antagonist (AM251; 1, 2.5, and $5 \mu \mathrm{M}$ ) on MCP-2 protein levels in poly-(I:C)-stimulated HaCaT cells, in the presence or absence of CBD $(20 \mu \mathrm{M})$. Our results show that when $\mathrm{HaCaT}$ cells were costimulated for 6 hours with poly-(I:C) and low concentrations of AM251 (1 or $2.5 \mu \mathrm{M})$, MCP-2 protein levels were comparable to those found in the absence of the antagonist (Fig. 7A). On the contrary, when $\mathrm{HaCaT}$ cells were costimulated with poly-(I:C) and the highest concentration of AM251 tested ( $5 \mu \mathrm{M})$, MCP-2 protein levels were comparable to those observed in the presence of $20 \mu \mathrm{M}$ CBD (Fig. 7A). In addition, when HaCaT cells were costimulated with poly-(I:C), $20 \mu \mathrm{M} \mathrm{CBD}$ and a per se inactive concentration of AM251 (2.5 $\mu \mathrm{M})$, MCP-2 production was comparable to that observed in poly-(I:C)-stimulated HaCaT cells treated with $20 \mu \mathrm{M}$ CBD alone (Fig. 7A). No effect was observed on MCP-2 protein levels after treatment of $\mathrm{HaCaT}$ cells with the antagonist AM251 alone (at the highest concentration tested, $5 \mu \mathrm{M}$ ), i.e., in the absence of poly-(I:C), as compared with vehicle-treated HaCaT cells (data not shown). Likewise, no additive effect was found on MCP-2 protein levels after that poly-(I:C)-stimulated HaCaT cells were treated with $20 \mu \mathrm{M}$ CBD and the highest concentration of AM251 tested (5 $\mu \mathrm{M})$, as compared with poly-(I:C)-stimulated HaCaT cells treated with $20 \mu \mathrm{M}$ CBD only (data not shown).

$\mathrm{CB}_{2}$ and TRPV1 Receptors Mediate the Action of CBD in Poly-(I:C)-Stimulated HaCaT Cells. We investigated the effect of a $\mathrm{CB}_{2}$ receptor antagonist (AM630; 0.01, 0.1, and $1 \mu \mathrm{M}$ ) and a TRPV1 receptor antagonist (I-RTX; 0.01, 0.1, and $1 \mu \mathrm{M}$ ) on MCP-2 protein levels in poly-(I:C)-stimulated HaCaT cells in the presence or absence of CBD $(20 \mu \mathrm{M})$. Our results show that when $\mathrm{HaCaT}$ cells were costimulated for 6 hours with poly-(I:C) and low concentrations of AM630 (0.01 or $0.1 \mu \mathrm{M})$ or high concentration of I-RTX (1 $\mu \mathrm{M})$, MCP-2 protein levels were comparable to those observed in the absence of the antagonists (Fig. 7B). On the contrary, when $\mathrm{HaCaT}$ cells were costimulated with poly-(I:C) and a higher concentration of AM630 $(1 \mu \mathrm{M})$ or lower concentrations of I-RTX $(0.01$ or $0.1 \mu \mathrm{M}), \mathrm{MCP}-2$ protein levels were comparable to those observed in the presence of CBD $20 \mu \mathrm{M}$ (Fig. 7B). Importantly, when HaCaT cells were costimulated with poly(I:C), $20 \mu \mathrm{M} \mathrm{CBD}$, and the highest per se inactive concentrations of AM630 or I-RTX ( 0.1 and $1 \mu \mathrm{M}$, respectively), MCP-2 chemokine production was comparable to that observed in poly-(I:C)-stimulated HaCaT cells treated with the vehicle (Fig. 7B). However, no effects of AM630 or I-RTX (0.1 and $1 \mu \mathrm{M}$, respectively) on MCP-2 protein levels were observed after 12 and 24 hours in poly-(I:C)-stimulated HaCaT cells treated with $20 \mu \mathrm{M} \mathrm{CBD}$, as compared with poly-(I:C)stimulated HaCaT cells treated with $20 \mu \mathrm{M}$ CBD alone (data not shown). In addition, no effect was observed on MCP-2 protein levels after that HaCaT cells were treated with the antagonists, AM630 or I-RTX, alone (at highest concentrations tested, $1 \mu \mathrm{M}$ ), i.e., in the absence of poly-(I:C), as compared with vehicle-treated $\mathrm{HaCaT}$ cells (data not shown). Likewise, no additive effects were found on MCP-2 protein
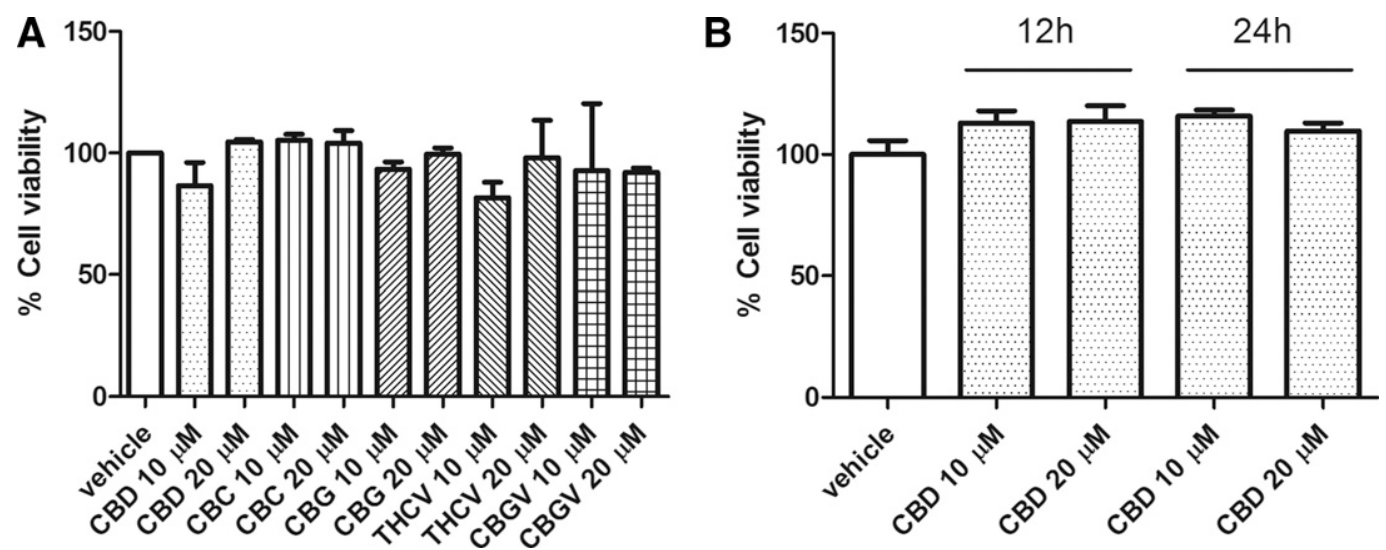

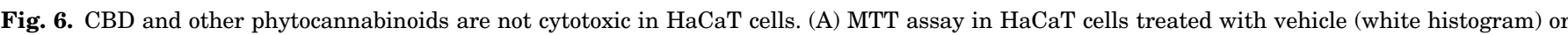

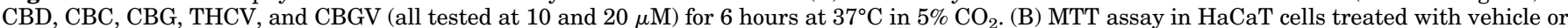

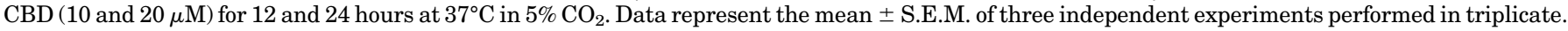




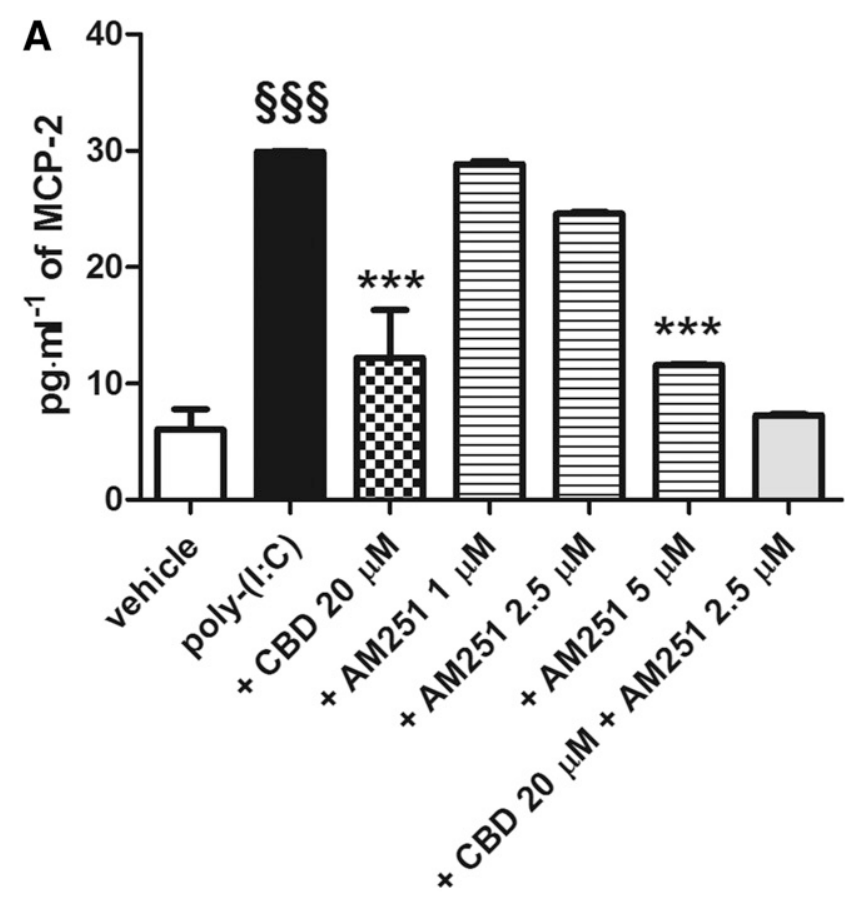

B

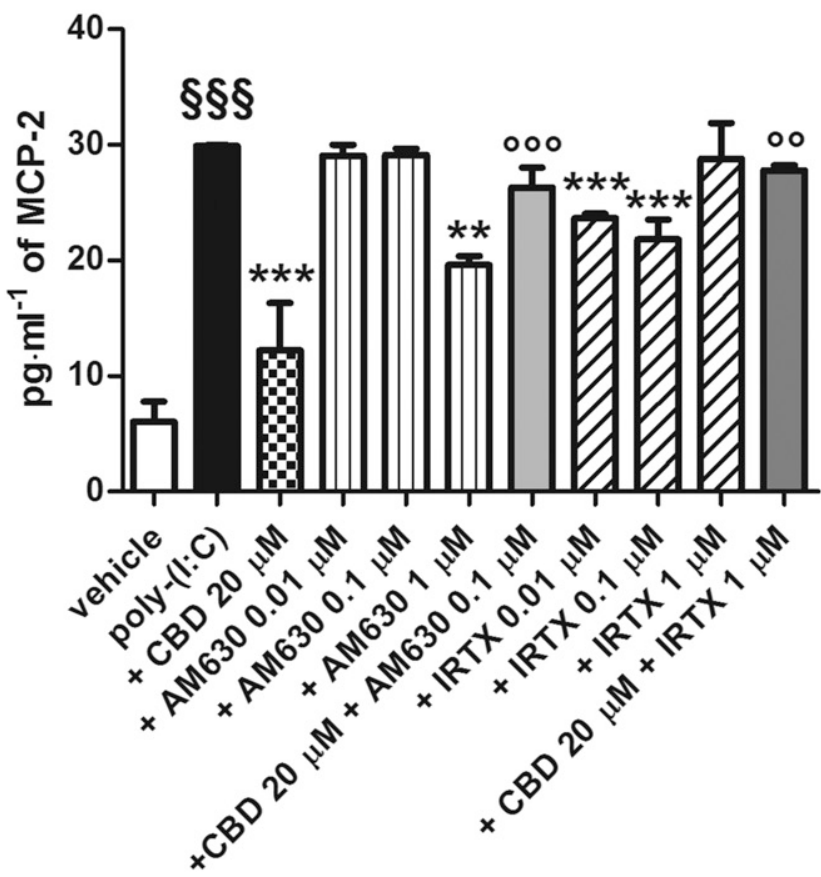

Fig. 7. $\mathrm{CB}_{2}$ and TRPV1 receptors mediate the action of CBD in poly-(I:C) stimulated HaCaT cells after 6 hours. (A) Enzyme-linked immunosorbent assay for MCP-2 release in the supernatants of poly-(I:C)-stimulated HaCaT cells $\left(100 \mu \mathrm{g} / \mathrm{ml}, 6\right.$ hours, $\left.37^{\circ} \mathrm{C}\right)$ treated with AM251 $(1,2.5$, and $5 \mu \mathrm{M})$ in the presence or absence of CBD $(20 \mu \mathrm{M})$. (B) Enzyme-linked immunosorbent assay for MCP-2 release in the supernatants of poly-(I:C)_ stimulated $\mathrm{HaCaT}$ cells $\left(100 \mu \mathrm{g} / \mathrm{ml}, 6\right.$ hours, $\left.37^{\circ} \mathrm{C}\right)$ treated with AM630 $(0.01$ and $0.1 \mu \mathrm{M})$ or I-RTX $(0.01$ and $0.1 \mu \mathrm{M})$ in the presence or absence of CBD $(20 \mu \mathrm{M})$. Data represent the mean \pm S.E.M. of three independent experiments performed in triplicate. ${ }^{\S \S \S} P<0.001$ vs. vehicle. ${ }^{* * *} P<0.001$; $* * P<0.01$ vs. poly-(I:C); ${ }^{\circ} \mathrm{P}<0.01 ;{ }^{\circ 0} \mathrm{P}<0.001$ vs. poly-(I:C) $+\mathrm{CBD}$ $20 \mu \mathrm{M}$. Assay range for MCP-2, $0.8-200 \mathrm{pg} / \mathrm{ml}$.

levels after that poly-(I:C)-stimulated HaCaT cells were treated with $20 \mu \mathrm{M}$ CBD and the highest concentration of AM630 tested $(1 \mu \mathrm{M})$ or the lowest concentrations of IRTX tested (0.01 and $0.1 \mu \mathrm{M})$, as compared with poly-(I:C)stimulated HaCaT cells treated with $20 \mu \mathrm{M}$ CBD (data not shown). On the basis of these results, we also investigated the effects of AM630 $(0.1 \mu \mathrm{M})$ and I-RTX $(1 \mu \mathrm{M})$ on the production of cytokines, such as IL-6, IL-8, and TNF- $\alpha$, in poly-(I:C)stimulated HaCaT cells in the presence or absence of CBD (20 $\mu \mathrm{M})$. Our results show that no effect was found with AM630 $(0.1 \mu \mathrm{M})$ or I-RTX $(1 \mu \mathrm{M})$ on the inhibitory action of CBD $(20 \mu \mathrm{M})$ on the levels of the other three cytokines that were elevated after poly-(I:C) stimulation of HaCaT cells (data not shown).

CBD Elevates AEA Levels in Poly-(I:C)-Stimulated HaCaT Cells. We measured the effect of CBD $(20 \mu \mathrm{M})$ on AEA, 2-AG, PEA, and OEA levels in poly-(I:C)-stimulated $\mathrm{HaCaT}$ cells. We observed that when HaCaT cells were stimulated for 6 hours with poly-(I:C), AEA levels were significantly increased by 3 -fold compared with vehicletreated HaCaT cells, and a nearly statistically significant trend toward elevation of PEA levels $(P=0.0633)$ was also observed (Fig. 8, A and C). When poly-(I:C)-stimulated HaCaT cells were treated with CBD $(20 \mu \mathrm{M})$, AEA levels were increased by 8 -fold compared with vehicle-treated HaCaT cells, and by 2.7-fold compared with poly-(I:C)-stimulated HaCaT cells (Fig. 8A). These increases were only observed during the early sensitization phase of ACD, i.e., after 6 hours (Fig. 8A). No consistent effect of CBD was observed on 2-AG and OEA levels after 6 hours (Fig. 8, B and D), as well as on AEA levels after 12 and 24 hours (data not shown), in poly-(I:C)stimulated $\mathrm{HaCaT}$ cells.

AEA and URB597 Reduce MCP-2, IL-6, and IL-8 Protein Levels in Poly-(I:C)-Stimulated HaCaT Cells. We investigated the effects of AEA and a selective fatty acid amide hydrolase inhibitor, URB597, on the production of MCP-2 and other cytokines (IL-6, IL-8, and TNF- $\alpha$ ) in poly(I:C)-stimulated HaCaT cells. Our results show that when HaCaT cells were costimulated with poly-(I:C) and AEA $(10 \mu \mathrm{M})$, the levels of MCP-2 and IL-8 proteins were reduced as compared with poly-(I:C)-stimulated $\mathrm{HaCaT}$ cells treated with the vehicle (Fig. 9, A and C). When HaCaT cells were costimulated with poly-(I:C) and URB597 $(10 \mu \mathrm{M})$, the levels of MCP-2, IL-6, and IL- 8 proteins were also reduced as compared with poly-(I:C)-stimulated HaCaT cells treated with the vehicle (Fig. 9). No effect was observed on IL-6 levels after treatment of poly-(I:C)-stimulated HaCaT cells with AEA (10 $\mu \mathrm{M})$ (Fig. 9B). Likewise, no effect was observed on TNF- $\alpha$ production after treatment of poly-(I: C)-stimulated HaCaT cells with either AEA $(10 \mu \mathrm{M})$ or URB597 (10 $\mu \mathrm{M})$ (data not shown). Thus, the effects of AEA and URB597 in poly-(I:C)-stimulated HaCaT cells were similar, although not identical, to those observed with CBD $(20 \mu \mathrm{M})$ (Fig. 9).

\section{Discussion}

In this study, we demonstrated for the first time that a nonpsychotropic plant cannabinoid, CBD, inhibits the production of the MCP-2 chemokine and other proinflammatory cytokines (i.e., IL-6, IL-8, and TNF- $\alpha$ ) in poly-(I:C)-stimulated keratinocytes more potently/efficaciously/dose-dependently than other nonpsychotropic phytocannabinoids tested here (CBDA, CBDV, CBDVA, CBC, CBG, CBGA, CBGV, THCV, 
A

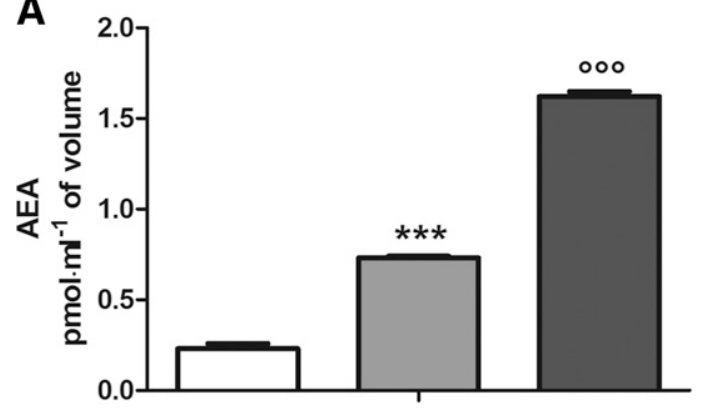

C

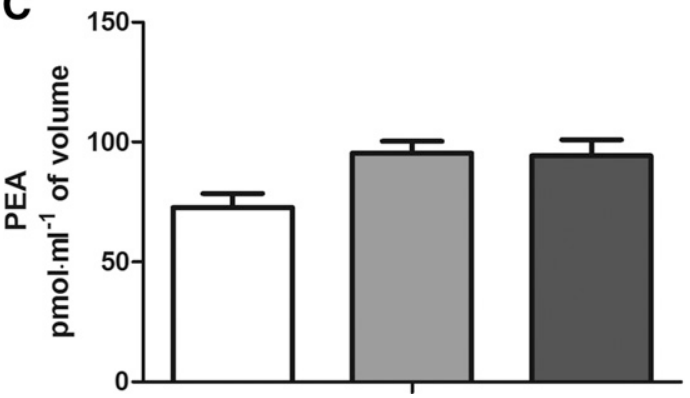

B

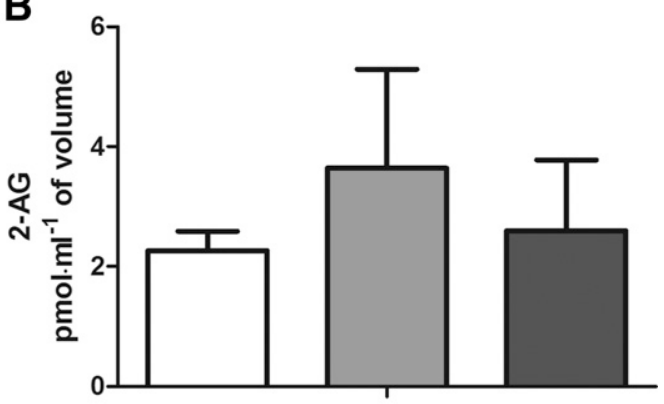

D

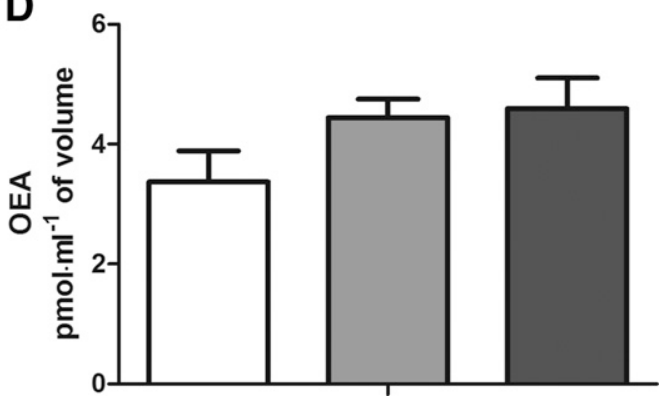

Fig. 8. CBD elevates AEA levels in poly-(I:C)-stimulated HaCaT cells after 6 hours. Concentrations of AEA (A), 2-AG (B), PEA (C), and OEA (D) in poly(I:C)-stimulated $\mathrm{HaCaT}$ cells $\left(100 \mu \mathrm{g} / \mathrm{ml}, 6\right.$ hours, $\left.37^{\circ} \mathrm{C}\right)$ in the presence of vehicle or $\mathrm{CBD}(20 \mu \mathrm{M})$. Data represent the mean \pm S.E.M. of three independent experiments performed in triplicate. ${ }^{* * *} P<0.001$ vs. vehicle; ${ }^{\circ{ }^{\circ}} P<0.001$ vs. poly-(I:C) + vehicle.

and THCVA). Importantly, we also identified the molecular targets for some of the actions of CBD on keratinocytes.

First, we demonstrated that when $\mathrm{HaCaT}$ cells are stimulated for 6 hours and up to 24 hours with an agonist of the toll-like receptor 3, i.e., poly-(I:C), they produce higher levels of MCP-2. This chemokine is a proinflammatory mediator involved in the recruitment of macrophages and mast cells into inflammatory sites (Taub et al., 1995; de Paulis et al., 2001 ), and is downregulated by $\mathrm{CB}_{1} / \mathrm{CB}_{2}$ agonists, such as THC and HU-210, in ear keratinocytes of mice with DNFB-induced ACD, as well as in poly-(I:C)-stimulated $\mathrm{HaCaT}$ cells in vitro (Karsak et al., 2007). We previously demonstrated that this chemokine can also be downregulated by an endogenous lipid mediator, namely PEA, which is known for its important anti-inflammatory properties and is currently used in the clinic against neuropathic and inflammatory pain but, unlike AEA, is not capable of directly activating $\mathrm{CB}_{1}$ or $\mathrm{CB}_{2}$ receptors (Iannotti et al., 2016). In particular, we showed that PEA at a concentration of $10 \mu \mathrm{M}$ was able to reduce, through a TRPV1-mediated mechanism, both the expression and the production of MCP-2 in poly-(I: C)-stimulated HaCaT cells in vitro (Petrosino et al., 2010). On the contrary, neither the antagonism of $\mathrm{CB}_{2}$ receptors nor the antagonism of peroxisome proliferator-activated receptor- $\alpha$ receptors reversed the anti-inflammatory effect of PEA in poly-(I:C)-stimulated HaCaT cells (Petrosino et al., 2010). Therefore, here we investigated 1) whether CBD, which, like PEA and unlike THC, is unable to directly activate $\mathrm{CB}_{1} / \mathrm{CB}_{2}$ receptors, can also nevertheless reduce MCP-2 protein levels in poly-(I:C)-stimulated $\mathrm{HaCaT}$ cell; and 2) the molecular target(s) through which CBD exerts this putative antiinflammatory action. We found that $\mathrm{CBD}$, in a concentrationdependent manner, strongly reduces MCP-2 protein levels in HaCaT cells stimulated for 6 hours and up to 24 hours with poly-(I:C), with the maximum effect being observed at the highest concentration tested $(20 \mu \mathrm{M})$, and no significant differences in the extent of the effect being noted at different time points. This concentration is 2-fold higher than the efficacious (and maximally soluble in the same vehicle) concentration of PEA (10 $\mu \mathrm{M})$, in the same in vitro model of ACD (Petrosino et al., 2010). Here, we also demonstrated for the first time that when HaCaT cells are stimulated for 6 hours and up to 24 hours with poly-(I:C), they produce higher levels of other proinflammatory cytokines (i.e., IL-6, IL-8, and TNF- $\alpha$ ), which, similar to MCP-2, are produced from keratinocytes during the sensitization phase (Barker, 1992; Enk and Katz, 1992; Becker and Knop, 1993), and that CBD also reduces these effects of poly-(I:C). However, of these three cytokines, only $\mathrm{TNF}-\alpha$ exhibited significant increases at all time points, suggesting their potentially different roles in different phases of inflammation, at least in this in vitro model.

Since it is well known that 1 ) the pharmacological blockade of $\mathrm{CB}_{2}$ receptor attenuates oxazoline-induced contact dermatitis in mice (Oka et al., 2006); 2) the activation of the $\mathrm{CB}_{2}$ receptor, but not the $\mathrm{CB}_{1}$ receptor, is involved in THC-induced 
A
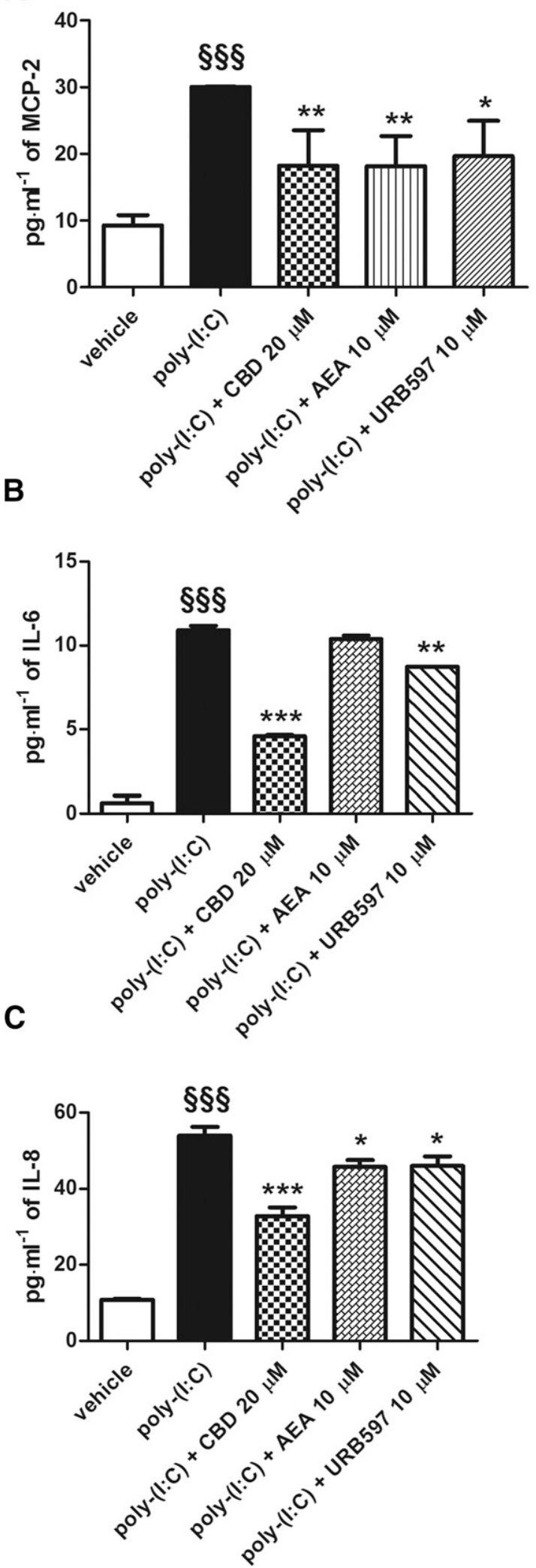

Fig. 9. AEA and URB597 reduce MCP-2, IL-6, and IL-8 levels in poly-(I: C)-stimulated $\mathrm{HaCaT}$ cells after 6 hours. Enzyme-linked immunosorbent assay for MCP-2 (A) and Bio-Plex Pro assay for IL-6 (B) and IL-8 (C) release in the supernatants of poly-(I:C)-stimulated HaCaT cells $\left(100 \mu \mathrm{g} / \mathrm{ml}, 6\right.$ hours, $\left.37^{\circ} \mathrm{C}\right)$ in the presence of vehicle or CBD $(20 \mu \mathrm{M})$, AEA $(10 \mu \mathrm{M})$, or URB597 $(10 \mu \mathrm{M})$. Data represent the mean \pm S.E.M. of three independent experiments performed in triplicate. ${ }^{\S \S \S} P<0.001 \mathrm{vs}$. anti-inflammatory effects (Yang et al., 2015; Shang, et al., 2016; Xie et al., 2016); 3) $\mathrm{CB}_{1}$ or $\mathrm{CB}_{2}$ receptor activation and the activation/desensitization of TRPV1 channels contribute to the in vitro and in vivo pharmacological actions of CBD (Costa et al., 2004; Arnold et al., 2012; Pazos et al., 2013; Stanley et al., 2015); 4) CBD can directly activate and desensitize TRPV1 channels (Iannotti et al., 2014); and 5) $\mathrm{CB}_{1}$ and $\mathrm{CB}_{2}$ receptors as well as TRPV1 are targets for the treatment of the early phase of ACD (Karsak et al., 2007; Petrosino et al., 2010), we investigated whether the antiinflammatory action of CBD could be mediated by one or more of these targets in the in vitro model of ACD. Although it is also known that CBD weakly activates the human 5-hydroxytryptamine (serotonin) receptor 1A (Russo et al., 2005), we did not investigate this mechanism because it has been demonstrated that $\mathrm{HaCaT}$ cells do not express such receptor (Slominski et al., 2003). Thus, we studied the effects of $\mathrm{CB}_{1}, \mathrm{CB}_{2}$, and TRPV1 antagonists on MCP-2 and cytokine (i.e., IL-6, IL-8, and TNF- $\alpha$ ) production in poly-(I:C)stimulated HaCaT cells in vitro, in the presence or absence of $20 \mu \mathrm{M}$ CBD. Our results show that, similar to $\mathrm{CBD}$, the $\mathrm{CB}_{1}$ antagonist AM251, at the highest concentration tested ( $5 \mu \mathrm{M})$, was able to only reduce MCP-2 protein levels after 6 hours in poly-(I:C)-stimulated HaCaT cells. The inhibitory effect of CBD on MCP-2 production was not influenced by the highest per se inactive concentration of AM251 $(2.5 \mu \mathrm{M})$. Similar to AM251 and CBD, the $\mathrm{CB}_{2}$ antagonist AM630, at the highest concentration tested ( $1 \mu \mathrm{M})$, was able to only reduce MCP-2 protein levels after 6 hours in poly-(I:C)-stimulated HaCaT cells, but unlike AM251, the highest per se inactive concentration of AM630 tested $(0.1 \mu \mathrm{M})$ was able to reverse the inhibitory effect of CBD on MCP-2 levels. On the other hand, low concentrations of the TRPV1 antagonist I-RTX were able to only reduce MCP-2 protein levels after 6 hours in poly-(I:C)-stimulated $\mathrm{HaCaT}$ cells, whereas the highest per se inactive concentration of this compound tested $(1 \mu \mathrm{M})$ was able to reverse the inhibitory effect of CBD on MCP-2 levels. These results 1) suggest that, since the effects of $\mathrm{CB}_{2}$ and TRPV1 antagonists, per se or on the effects of CBD, were only observed on MCP-2 production and only at 6 hours, this chemokine and these receptors are mostly involved in the early sensitization phase of ACD and in the inhibitory actions thereupon of the phytocannabinoid; the effect of the highest concentrations of AM251 per se may be non- $\mathrm{CB}_{1}$-mediated, since this compound at high concentrations acts as an agonist on another potential anti-inflammatory off-target, that is GPR55 (Ryberg et al., 2007; Cantarella et al., 2011; Montecucco et al., 2016); 2) confirm that $\mathrm{CB}_{2}$ receptors may play also a facilitatory role in ACD (Ueda et al., 2005), as indicated here by the antiinflammatory effect of the highest concentration of AM630; and 3) support the previous finding that TRPV1 may play both facilitatory and inhibitory roles against ACD (Banvolgyi et al., 2005), as shown here by the fact that low, but not high, concentrations of I-RTX counteracted poly-(I:C)-induced MCP-2 production in HaCaT keratinocytes. Thus, the antiinflammatory effect of CBD might be due to both $\mathrm{CB}_{2}$ activation, as previously shown for THC (Karsak et al., 2007; Yang et al., 2015; Shang et al., 2016; Xie et al., 2016), and

vehicle; $* P<0.05 ; * * P<0.01 ; * * * P<0.001$ vs. poly-(I:C). Assay range for MCP-2, 0.8-200 pg/ml; for IL-6, $37.68 \mathrm{pg} / \mathrm{ml}$; and for IL-8, $42.15 \mathrm{pg} / \mathrm{ml}$. 
TRPV1 activation/desensitization, as suggested here by the fact that this effect was reversed by both a low concentration of a $\mathrm{CB}_{2}$ receptor antagonist (AM630) and by a high concentration of a TRPV1 antagonist (I-RTX). Although this latter effect is not surprising due to the aforementioned capability of CBD to stimulate and desensitize TRPV1 (Iannotti et al., 2014), this phytocannabinoid exhibits only low affinity for $\mathrm{CB}_{2}$ (Pertwee, 2008). Therefore, we hypothesized that endogenous ligands could mediate the anti-inflammatory effect of CBD at this receptor thus explaining why such effect was antagonized by AM630. Indeed, CBD, at a $\sim 20 \mu \mathrm{M}$ concentration $\left(\mathrm{IC}_{50}=27.5\right.$ $\mu \mathrm{M})$ inhibits both AEA cellular uptake and enzymatic hydrolysis (Bisogno et al., 2001), and these effects could explain both the present finding of its stimulatory action on AEA levels and indirect activation of $\mathrm{CB}_{2}$ receptors. Consequently, our hypothesis that $\mathrm{CBD}$ acted via elevation of AEA levels in HaCaT cells was supported by our present finding that both AEA and a synthetic inhibitor of its degradation, URB597, similar to $\mathrm{CBD}$, were able to reduce the production of both MCP-2 and other proinflammatory cytokines (i.e., IL-6 and IL-8) produced by poly-(I:C)-stimulated keratinocytes. Interestingly, the stimulatory action of CBD on AEA levels was only observed after 6 hours, and this could explain why the $\mathrm{CB}_{2}$ antagonist here did not attenuate the antiinflammatory effects of CBD after 12 and 24 hours. Importantly, whereas the effects of AEA and URB597 on MCP-2 production were comparable to those of CBD, those on IL-6 and IL-8 were statistically significant but less efficacious. This observation supports the aforementioned suggestion that these cytokines play different roles in the sensitization phase of ACD, at least in the in vitro model used here, thus possibly explaining why $\mathrm{CB}_{2}$ and TRPV1 antagonists did not attenuate the effect of CBD on these inflammatory mediators.

In conclusion, in the present study, we demonstrated that, in an in vitro model of ACD, 1) CBD inhibits the production of MCP2 as well as IL-6, IL- 8 , and TNF- $\alpha$; 2 ) the endogenous levels of AEA are increased after CBD treatment; and 3) the antiinflammatory effect of CBD during the early sensitization phase (i.e., after 6 hours) is antagonized both by a selective $\mathrm{CB}_{2}$ antagonist_and hence potentially mediated by the endogenous agonist for $\mathrm{CB}_{2}$ receptors, AEA-and a selective TRPV1 antagonist-likely because the phytocannabinoid can directly activate and desensitize the TRPV1 channel. Given the established safety profile of CBD in humans (Leweke et al., 2012; Pertwee, 2015), these data warrant further experiments on the preclinical testing of this compound in animal models of ACD.

\section{Authorship Contributions}

Participated in research design: Petrosino, Iuvone, Di Marzo.

Conducted experiments: Petrosino, Verde, Vaia, Allarà, Iuvone.

Performed data analysis: Petrosino, Di Marzo.

Wrote or contributed to the writing of the manuscript: Petrosino, Di Marzo.

\section{References}

Arnold JC, Hone P, Holland ML, and Allen JD (2012) CB2 and TRPV1 receptors mediate cannabinoid actions on MDR1 expression in multidrug resistant cells. Pharmacol Rep 64:751-757.

Bánvölgyi A, Pálinkás L, Berki T, Clark N, Grant AD, Helyes Z, Pozsgai G, Szolcsányi J, Brain SD, and Pintér E (2005) Evidence for a novel protective role of the vanilloid TRPV1 receptor in a cutaneous contact allergic dermatitis model. $J$ Neuroimmunol 169:86-96.

Barker JN (1992) Role of keratinocytes in allergic contact dermatitis. Contact Dermat 26:145-148.

Becker D and Knop J (1993) Mechanism in allergic contact dermatitis. Exp Dermatol 2:63-69.
Bisogno T, Hanus L, De Petrocellis L, Tchilibon S, Ponde DE, Brandi I, Moriello AS, Davis JB, Mechoulam R, and Di Marzo V (2001) Molecular targets for cannabidiol and its synthetic analogues: effect on vanilloid VR1 receptors and on the cellular uptake and enzymatic hydrolysis of anandamide. Br J Pharmacol 134:845-852.

Bisogno T, Sepe N, Melck D, Maurelli S, De Petrocellis L, and Di Marzo V (1997) Biosynthesis, release and degradation of the novel endogenous cannabimimetic metabolite 2-arachidonoylglycerol in mouse neuroblastoma cells. Biochem $J \mathbf{3 2 2}$ 671-677.

Burstein S (2015) Cannabidiol (CBD) and its analogs: a review of their effects on inflammation. Bioorg Med Chem 23:1377-1385.

Burstein SH and Zurier RB (2009) Cannabinoids, endocannabinoids, and related analogs in inflammation. AAPS J 11:109-119.

Cantarella G, Scollo M, Lempereur L, Saccani-Jotti G, Basile F, and Bernardini R (2011) Endocannabinoids inhibit release of nerve growth factor by inflammationactivated mast cells. Biochem Pharmacol 82:380-388.

Costa B, Giagnoni G, Franke C, Trovato AE, and Colleoni M (2004) Vanilloid TRPV1 receptor mediates the antihyperalgesic effect of the nonpsychoactive cannabinoid, cannabidiol, in a rat model of acute inflammation. Br J Pharmacol 143:247-250

de Paulis A, Annunziato F, Di Gioia L, Romagnani S, Carfora M, Beltrame C, Marone $\mathrm{G}$, and Romagnani P (2001) Expression of the chemokine receptor CCR3 on human mast cells. Int Arch Allergy Immunol 124:146-150.

De Petrocellis L, Davis JB, and Di Marzo V (2001) Palmitoylethanolamide enhances anandamide stimulation of human vanilloid VR1 receptors. FEBS Lett 506: $253-256$.

De Petrocellis L, Ligresti A, Moriello AS, Allarà M, Bisogno T, Petrosino S, Stott CG, and Di Marzo V (2011) Effects of cannabinoids and cannabinoid-enriched Cannabis extracts on TRP channels and endocannabinoid metabolic enzymes. Br J Pharmacol 163:1479-1494.

Di Marzo V, Goparaju SK, Wang L, Liu J, Bátkai S, Járai Z, Fezza F, Miura GI, Palmiter RD, Sugiura T, et al. (2001) Leptin-regulated endocannabinoids are involved in maintaining food intake. Nature 410:822-825.

Enk AH and Katz SI (1992) Early events in the induction phase of contact sensitivity. $J$ Invest Dermatol 99:39S-41S.

Gaffal E, Cron M, Glodde N, and Tüting T (2013) Anti-inflammatory activity of topical THC in DNFB-mediated mouse allergic contact dermatitis independent of CB1 and CB2 receptors. Allergy 68:994-1000.

Iannotti FA, Di Marzo V, and Petrosino S (2016) Endocannabinoids and endocannabinoid-related mediators: targets, metabolism and role in neurological disorders. Prog Lipid Res 62:107-128.

Iannotti FA, Hill CL, Leo A, Alhusaini A, Soubrane C, Mazzarella E, Russo E, Whalley BJ, Di Marzo V, and Stephens GJ (2014) Nonpsychotropic plant cannabinoids, cannabidivarin (CBDV) and cannabidiol (CBD), activate and desensitize transient receptor potential vanilloid 1 (TRPV1) channels in vitro: potential for the treatment of neuronal hyperexcitability. ACS Chem Neurosci $\mathbf{5}$ : 1131-1141.

Karsak M, Gaffal E, Date R, Wang-Eckhardt L, Rehnelt J, Petrosino S, Starowicz K, Steuder R, Schlicker E, Cravatt B, et al. (2007) Attenuation of allergic contact dermatitis through the endocannabinoid system. Science 316:1494-1497.

Leweke FM, Piomelli D, Pahlisch F, Muhl D, Gerth CW, Hoyer C, Klosterkötter J, Hellmich M, and Koethe D (2012) Cannabidiol enhances anandamide signaling and alleviates psychotic symptoms of schizophrenia. Transl Psychiatry 2:e94.

Lo Verme J, Fu J, Astarita G, La Rana G, Russo R, Calignano A, and Piomelli D (2005) The nuclear receptor peroxisome proliferator-activated receptor-alpha mediates the anti-inflammatory actions of palmitoylethanolamide. Mol Pharmacol 67 $15-19$

Maione S, Piscitelli F, Gatta L, Vita D, De Petrocellis L, Palazzo E, de Novellis V, and Di Marzo V (2011) Non-psychoactive cannabinoids modulate the descending pathway of antinociception in anaesthetized rats through several mechanisms of action. Br J Pharmacol 162:584-596.

Marsicano G, Wotjak CT, Azad SC, Bisogno T, Rammes G, Cascio MG, Hermann H, Tang J, Hofmann C, Zieglgänsberger W, et al. (2002) The endogenous cannabinoid system controls extinction of aversive memories. Nature 418:530-534.

Montecucco F, Bondarenko AI, Lenglet S, Burger F, Piscitelli F, Carbone F, Roth A, Liberale L, Dallegri F, Brandt KJ, et al. (2016) Treatment with the GPR55 antagonist CID16020046 increases neutrophil activation in mouse atherogenesis. Thromb Haemost 116:987-997.

Oka S, Wakui J, Ikeda S, Yanagimoto S, Kishimoto S, Gokoh M, Nasui M, and Sugiura T (2006) Involvement of the cannabinoid CB2 receptor and its endogenous ligand 2-arachidonoylglycerol in oxazolone-induced contact dermatitis in mice. J Immunol 177:8796-8805.

Pazos MR, Mohammed N, Lafuente H, Santos M, Martínez-Pinilla E, Moreno E, Valdizan E, Romero J, Pazos A, Franco R, et al. (2013) Mechanisms of cannabidiol neuroprotection in hypoxic-ischemic newborn pigs: role of 5HT(1A) and CB2 receptors. Neuropharmacology 71:282-291.

Pertwee RG (2008) The diverse CB1 and CB2 receptor pharmacology of three plant cannabinoids: delta9-tetrahydrocannabinol, cannabidiol and delta9-tetrahydrocannabivarin. Br J Pharmacol 153:199-215.

Pertwee RG (2015) Endocannabinoids and their pharmacological actions. Handb Exp Pharmacol 231:1-37.

Petrosino S, Cristino L, Karsak M, Gaffal E, Ueda N, Tüting T, Bisogno T, De Filippis D, D'Amico A, Saturnino C, et al. (2010) Protective role of palmitoylethanolamide in contact allergic dermatitis. Allergy 65:698-711.

Petrosino S and Di Marzo V (2017) The pharmacology of palmitoylethanolamide and first data on the therapeutic efficacy of some of its new formulations. Br J Pharmacol 174:1349-1365.

Petrosino S, Schiano Moriello A, Cerrato S, Fusco M, Puigdemont A, De Petrocellis L, and Di Marzo V (2016) The anti-inflammatory mediator palmitoylethanolamide enhances the levels of 2-arachidonoyl-glycerol and potentiates its actions at TRPV1 cation channels. Br J Pharmacol 173:1154-1162. 
Russo EB, Burnett A, Hall B, and Parker KK (2005) Agonistic properties of cannabidiol at 5-HT1a receptors. Neurochem Res 30:1037-1043.

Ryberg E, Larsson N, Sjögren S, Hjorth S, Hermansson NO, Leonova J, Elebring T, Nilsson K, Drmota T, and Greasley PJ (2007) The orphan receptor GPR55 is a novel cannabinoid receptor. Br J Pharmacol 152:1092-1101.

Shang VC, Kendall DA, and Roberts RE (2016) $\Delta^{9}$-Tetrahydrocannabinol reverse $\mathrm{TNF} \alpha$-induced increase in airway epithelial cell permeability through $\mathrm{CB}_{2}$ receptors. Biochem Pharmacol 120:63-71.

Slominski A, Pisarchik A, Zbytek B, Tobin DJ, Kauser S, and Wortsman J (2003) Functional activity of serotoninergic and melatoninergic systems expressed in the skin. J Cell Physiol 196:144-153.

Stanley CP, Hind WH, Tufarelli C, and O'Sullivan SE (2015) Cannabidiol cause endothelium-dependent vasorelaxation of human mesenteric arteries via CB1 activation. Cardiovasc Res 107:568-578.

Taub DD, Proost P, Murphy WJ, Anver M, Longo DL, van Damme J, and Oppenheim JJ (1995) Monocyte chemotactic protein-1 (MCP-1), -2, and -3 are chemotactic for human T lymphocytes. J Clin Invest 95:1370-1376.

Ueda Y, Miyagawa N, Matsui T, Kaya T, and Iwamura H (2005) Involvement of cannabinoid $\mathrm{CB}(2)$ receptor-mediated response and efficacy of cannabinoid $\mathrm{CB}(2)$ receptor inverse agonist, JTE-907, in cutaneous inflammation in mice. Eur $J$ Pharmacol 520:164-171.
Vaia M, Petrosino S, De Filippis D, Negro L, Guarino A, Carnuccio R, Di Marzo V, and Iuvone T (2016) Palmitoylethanolamide reduces inflammation and itch in a mouse model of contact allergic dermatitis. Eur J Pharmacol 791:669-674.

van Loveren H, Meade R, and Askenase PW (1983) An early component of delayed-type hypersensitivity mediated by T cells and mast cells. J Exp Med 157:1604-1617.

Watanabe H, Unger M, Tuvel B, Wang B, and Sauder DN (2002) Contact hypersensitivity: the mechanism of immune responses and $\mathrm{T}$ cell balance. $J$ Interferon Cytokine Res 22:407-412

Xie J, Xiao D, Xu Y, Zhao J, Jiang L, Hu X, Zhang Y, and Yu L (2016) Up-regulation of immunomodulatory effects of mouse bone-marrow derived mesenchymal stem cells by tetrahydrocannabinol pre-treatment involving cannabinoid receptor CB2. Oncotarget 7:6436-6447.

Yang L, Li FF, Han YC, Jia B, and Ding Y (2015) Cannabinoid receptor CB2 is involved in tetrahydrocannabinol-induced anti-inflammation against lipopolysaccharide in MG-63 cells. Mediators Inflamm 2015:362126.

Address correspondence to: Dr. Vincenzo Di Marzo, Istituto di Chimica Biomolecolare, Consiglio Nazionale delle Ricerche, Via Campi Flegrei 34, 80078 Pozzuoli, Napoli, Italy. E-mail: vdimarzo@icb.cnr.it 